\title{
Phosphorus Fraction in a Yellow Latosol Cropped Under No-tilage System in the Brazilian Amazon
}

\author{
Rubia Carla Ribeiro Dantas (Corresponding author) \\ Federal Rural University of Amazon, 066.077-830, Belém, Pará, Brazil. E-mail: \\ ribeirorubiaa8@gmail.com
}

Edilson Carvalho Brasil

Embrapa Amazônia Oriental, 66095-903, Belém, Pará, Brazil.

E-mail:edilson.brasil@embrapa.com

Mário Lopes da Silva Júnior

Federal Rural University of Amazon, 066.077-830, Belém, Pará, Brazil. E-mail: mario.silva_junior@yahoo.com.br

Marcos André Piedade Gama

Federal Rural University of Amazon, 066.077-830, Belém, Pará, Brazil. E-mail: gama_map@yahoo.com.br

Received: Mar. 15, 2020

doi:10.5296/jas.v8i3.16668
Accepted: Apr. 12, 2020

Published: Apr. 14, 2020

URL: https://doi.org/10.5296/jas.v8i3.16668

\begin{abstract}
Phosphorus (P) deficiency is one of the main factors that limits productivity in Brazilian soils. However, soil management under no-tillage system (NT) may alter the availability of P in the soil. The objective of this study was to evaluate the dynamics of $\mathrm{P}$ fractions in a dystrophic Yellow Latosol, cropped under no-tillage for a long period of time in the Amazon Biome. The study was conducted on a farm located in the municipality of Paragominas, southeastern Pará. This experiment evaluated plots cultivated in plots at nine (NT9), 11 (NT11) and 13 (NT13) years of no-tillage system adoption, in one plot under conventional cultivation system (CS) and a surrounding area under native forest (NF) at depths of 0-10, 10-20, 20-30 and 30-40 cm. The soil samples were subjected to $\mathrm{P}$ chemical fractionation to determine the different
\end{abstract}


fractions. The soil management systems showed differential capacity of $\mathrm{P}$ accumulation. In the areas under no-tillage, $\mathrm{P}$ is accumulated in the toplayer and drastically reduced with depth, while in CS, this reduction is less pronounced. In the $0-20 \mathrm{~cm}$ depth layer during the adopted period of the no-tillage system, it was observed an increase in the content of inorganic phosphorus extracted by resin and $0.5 \mathrm{M} \mathrm{NaHCO}_{3}$ ( $\mathrm{Pi}_{\text {AER }}$ and PiBIC) and organic phosphorus extracted by $0.5 \mathrm{M} \mathrm{NaHCO}$ (PoBIC), fractions considered as available for Biomass. Regardless of the year of adoption, the no-tillage system was superior to CS and NF. This was also observed for the inorganic and organic fractions extracted by $\mathrm{NaOH} 0.1 \mathrm{M}$ (PiHid-0.1 and PoHid-0.1) and inorganic fraction extracted by $\mathrm{HCl} 1 \mathrm{M}\left(\mathrm{P}_{\mathrm{iHCl}}\right)$.

Keywords: depth, lability, management systems

\section{Introduction}

Large-scale grain farming in Brazil has advanced to areas of the Amazon Biome in the North of the country in the last decade (Persson et al., 2014; Mapa, 2018). The expansion of the agricultural frontier in the Brazilian Amazon is being driven mainly by the cultivation of grains (corn/soybeans). It is estimated that in the next 10 years there will be an increase by $27 \%$ in production and $15 \%$ in the cropped area of grains in Brazil, which is the highest increase estimated for the North of the country (Mapa, 2018).

Highly weathered soils predominate in this region. Besides, climatic conditions (high rainfall, high temperatures, low availability and high $\mathrm{P}$ adsorption capacity) require the use of a conservationist soil management system, since the conversion of natural systems to conventional agricultural practices significantly alters the biogeochemical conditions of the soil (Petter et al., 2017). The conventional system (CS) is the one commonly used for grain production. It allows high productivity and profitability of crops. However, it is considered as the most degrading for tropical soils, with high oxidation power of soil organic matter (SOM) and increase in P adsorption (Pavinato and Rosolem, 2008). In soils where $\mathrm{P}$ is a limiting factor for productivity, as is the case of most soils in the Amazon, the use of $\mathrm{C}$ becomes inadequate due to the negative effects on the dynamics of $\mathrm{P}$ in the soil, caused by soil inversion and the decrease in SOM levels, which favors the adsorption of $\mathrm{P}$ to soil colloids (Fink et al., 2016; Tiecher et al, 2012a). The no-tillage system (NT) has been adopted for almost four decades in regions in the south and southeast of Brazil and has been showing improvement or at least maintainance of soil quality, at the same time, providing adequate productivity for crops (Hollingeret al., 2005; Lal et al., 2007; López et al., 2012; Melero et al., 2009). In addition, the NT promotes nutrient cycling, especially P, by increasing the biological activity in the soil (Frasier et al., 2016).

Phosphorus in the soil is found in fractions with different levels of availability for crops and understanding the chemistry of these fractions is of great importance for the establishment of adequate soil management, which guarantees the increase of nutrient availability in the soil-plant system (Pavinato and Rosolem, 2008; De Oliveira et al., 2015).

The method of sequential extraction of $\mathrm{P}$ allows the characterization of different fractions of inorganic (Pi) and organic (Po) P, on a solubility variation scale based on changes in different 
pH levels and extractive power, in decreasing order of lability in the soil (Hedley et al., 1982). This type of analytical procedure has been used in experiments in order to clarify the chemical transformations that occur with the various $\mathrm{P}$ fractions in the soil, depending on the adopted use and management of the soil (Barej et al., 2014; Negassa and Leinweber, 2009; Pavinato et al., 2009).

Studies conducted in the south and southeast regions of Brazil show that the NT promotes the accumulation of $\mathrm{P}$ in fractions of greater lability or greater availability for absorption by plants (Fink et al., 2016; Rodrigues et al., 2015; Tiecher et al., 2012a). With the time of adoption, this process may represent a significant decrease in the amounts of phosphate fertilizers in areas managed under NT, with the possibility of obtaining higher yields using the same amounts of fertilizers recommended for the CS (Lopes et al., 2004).

In the Brazilian Amazon region, where climatic conditions indicate high levels of rainfall and high temperatures throughout the year, favoring a strong change in the dynamics of SOM and in the soil P, as a result (Luizao, 2007; Makewitz et al., 2003). In this region, studies related to P dynamics in the soil has been carried out exclusively in pasture areas (Costa et al., 2015), conventional cultivation system (Trindade et al., 2011) and areas with secondary vegetation subjected to crushing of the Biomass for soil cover (Farias et al., 2015). However, there are few studies conducted in areas under NT in conditions of the Amazon Biome, which consider the time of adoption of this system, indicating the need for further and more detailed studies related to this theme.

Therefore, the objective of this work was to expand the understanding of the $\mathrm{P}$ in the chemistry of the soil when cultivated in different periods of time under no-tillage system in the Amazon Biome, using the fractionation method with sequential extraction of $\mathrm{P}$.

\section{Material and Methods}

\section{Study Site}

The study was conducted on two commercial grain-production farms $\left(03^{\circ} 15^{\prime} 30.4^{\prime \prime} \mathrm{S}\right.$, $\left.047^{\circ} 16^{\prime} 51.3^{\prime \prime} \mathrm{W}\right)$ and (0315'11.1”S, 047 $\left.16^{\circ} 39.8^{\prime} \mathrm{W}\right)$ located along PA 125 highway, $30 \mathrm{~km}$ away from the headquarters of the municipality of Paragominas, state of Pará, in the northeast of the Brazilian Amazon. The climate in the region is classified as "Awi" according to Köppen (Bastos et al., 2005), with an average annual precipitation of 1,800 $\mathrm{mm}$ and an average annual temperature of $26.9^{\circ} \mathrm{C}$ (Bastos et al., 2005). The soil was classified as dystrophic Yellow Latosol, clayey texture, whose physical attributes at the 0-20 cm depth showed the following values: 27, 12, 242 and $719 \mathrm{~g} \mathrm{~kg}^{-1}$ of fine sand, coarse sand, silt and clay, respectively (Donagema et al., 2011).

\section{Study area characterization and treatments}

The study area was first under pasture until 2000, when it was converted to grain production. From 2001, the areas started to be cultivated with annual agricultural cycles of corn, followed by soybeans in the following annual cycle, using subsowing with Urochloa ruziziensis cover species, in all agricultural cycles. 


\section{Macrothink}

Journal of Agricultural Studies

ISSN 2166-0379

2020, Vol. 8, No. 3

For the conduction of the experiment, in 2016, the area was divided into plots according to the date of implementation of the management systems, which were considered as treatments and consisted of: succession of crops under no-tillage system at nine years of implantation (NT9); at 11 years of implementation (NT11); at 13 (NT13) years of implementation; conventional cropping system (CS) at 1 year of implantation; and surrounding area under native forest (NF), used as a control standard. All treatments were under the same climatic condition, topography and soil type, differing only for the year of implementation of the management and land use systems (Table 1).

Table 1. Establishment of the year and crop sequences in the plots under no-tillage system and conventional cropping system in the municipality of Paragominas, PA ${ }^{(1)}$

\begin{tabular}{|c|c|c|c|c|}
\hline \multirow{2}{*}{$\begin{array}{l}\text { Establishment } \\
\text { of the year }\end{array}$} & $\mathrm{CS}$ & NT9 & NT11 & NT13 \\
\hline & \multicolumn{4}{|c|}{ 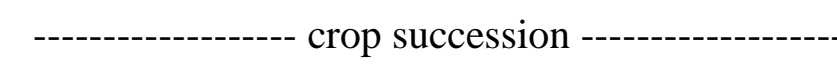 } \\
\hline 2003 & & & & Rice \\
\hline 2004 & & & & Corn \\
\hline 2005 & & & Rice/corn & Corn \\
\hline 2006 & & & Corn & Soybeans \\
\hline 2007 & & Rice & Corn & Corn \\
\hline 2008 & & Corn & Corn & Corn \\
\hline 2009 & & Corn & Corn & Soybeans \\
\hline 2010 & & Soybeans & Soybeans & Corn \\
\hline 2011 & & Corn & Corn & Soybeans \\
\hline 2012 & & Soybeans & Soybeans & Corn \\
\hline 2013 & & Corn & Corn & Soybeans \\
\hline 2014 & & Corn & Corn & Soybeans \\
\hline 2015 & & Soybeans & Soybeans & Corn \\
\hline 2016 & Soybeans & Corn & Corn & Soybeans \\
\hline area & 80 há & 42 há & 77 há & 85 há \\
\hline
\end{tabular}

(1) CS: conventional cropping system for one year; NT9: 9-year no-tillage system; NT11: 11-year no-tillage system; NT13: 13-year no-tillage system. 
All cropped areas received liming and fertilization at amounts estimated based on the results of soil analysis, carried out in the years preceding the cultivation.

\section{Soil sampling}

For the initial chemical characterization of the soil and the fractionation of $\mathrm{P}$, soil samples were collected in the agricultural year of 2016 in all treatments (Table 2), following the procedure described below.

Table 2. Chemical attributes in a dystrophic Yellow Latosol in the 2016 agricultural year under different use and managements systems in the municipality of Paragominas, PA ${ }^{(1)}$

\begin{tabular}{|c|c|c|c|c|c|c|c|c|c|c|}
\hline \multirow{2}{*}{$\begin{array}{c}\text { managemen } \\
\text { ts systems }\end{array}$} & depth & $\mathrm{OM}$ & $\mathrm{pH}$ & $\mathrm{P}$ & $\mathrm{K}$ & $\mathrm{Ca}$ & $\mathrm{Ca}+\mathrm{Mg}$ & $\mathrm{Al}$ & CEC & \multirow{2}{*}{$\frac{\mathrm{V}}{\%}$} \\
\hline & $(\mathrm{cm})$ & $\mathrm{g} / \mathrm{kg}$ & $\left(\mathrm{H}_{2} \mathrm{O}\right)$ & \multicolumn{6}{|c|}{-------------------mg/dm³ } & \\
\hline \multirow{4}{*}{ NF } & $0-10$ & 50.3 & 4.7 & 3 & 0.11 & 4.4 & 5.3 & 0.6 & 11.8 & 46.3 \\
\hline & $10-20$ & 26.5 & 4.6 & 2 & 0.09 & 1.8 & 2.4 & 0.6 & 7.6 & 32.3 \\
\hline & $20-30$ & 19.3 & 4.6 & 2 & 0.05 & 1.3 & 1.7 & 0.7 & 6.2 & 29.1 \\
\hline & $30-40$ & 16.5 & 4.5 & 2 & 0.04 & 0.9 & 1.2 & 0.7 & 5.5 & 23.4 \\
\hline \multirow{4}{*}{$\mathrm{CS}$} & $0-10$ & 45.5 & 5.9 & 8 & 0.47 & 6.4 & 8.2 & 0.1 & 11.3 & 76.9 \\
\hline & $10-20$ & 26.2 & 5.3 & 3 & 0.33 & 3.3 & 4.0 & 0.1 & 8.3 & 51.8 \\
\hline & $20-30$ & 21.0 & 5.1 & 3 & 0.25 & 2.6 & 3.4 & 0.2 & 7.1 & 50.7 \\
\hline & $30-40$ & 16.8 & 4.7 & 2 & 0.19 & 1.7 & 2.3 & 0.6 & 6.2 & 39.8 \\
\hline \multirow{4}{*}{ NT9 } & $0-10$ & 51.6 & 5.0 & 11 & 0.73 & 3.3 & 4.9 & 0.2 & 11.8 & 48.5 \\
\hline & $10-20$ & 35.6 & 5.1 & 12 & 0.67 & 2.7 & 3.9 & 0.2 & 10.1 & 45.4 \\
\hline & $20-30$ & 37.1 & 4.9 & 11 & 0.8 & 2.7 & 4.0 & 0.2 & 10.5 & 45.9 \\
\hline & $30-40$ & 22.4 & 4.8 & 4 & 0.35 & 1.5 & 2.1 & 0.3 & 6.9 & 36.4 \\
\hline \multirow{4}{*}{ NT11 } & $0-10$ & 41.9 & 5.3 & 20 & 0.43 & 3.9 & 4.9 & 0.1 & 10.9 & 49.2 \\
\hline & $10-20$ & 32.0 & 5.4 & 16 & 0.38 & 3.4 & 4.2 & 0.1 & 10.0 & 46.2 \\
\hline & $20-30$ & 34.0 & 5.3 & 12 & 0.37 & 3.2 & 3.9 & 0.2 & 9.1 & 47.5 \\
\hline & $30-40$ & 20.2 & 5.0 & 5 & 0.23 & 1.8 & 2.2 & 0.2 & 6.2 & 38.7 \\
\hline \multirow{4}{*}{ NT13 } & $0-10$ & 64.2 & 5.9 & 29 & 0.88 & 5.0 & 6.6 & 0.1 & 10.3 & 73.0 \\
\hline & $10-20$ & 33.9 & 5.3 & 13 & 0.44 & 2.9 & 3.5 & 0.1 & 7.9 & 50.4 \\
\hline & $20-30$ & 19.5 & 5.0 & 5 & 0.25 & 2.2 & 2.8 & 0.2 & 6.3 & 48.3 \\
\hline & $30-40$ & 18.0 & 4.9 & 4 & 0.19 & 1.8 & 2.2 & 0.3 & 5.6 & 41.8 \\
\hline
\end{tabular}

Because of the large extension of the study area, it was decided to use the sampling methodology proposed by Rotta et al. (2015). In each treatment, polygons corresponding to the area of the plots were demarcated, and the geographic coordinates were recorded using GPS. Next, coordinates were plotted on satellite image, using the ArcGIS software (version 10.5), for the establishment of $100 \times 100$-meter squares (Figure 1). The boxes were enumerated for randomize and four sample areas were defined within each treatment, which 


\section{Macrothink}

corresponded to the repetitions. In each sampling area (repetition), 20 simple samples were taken to compose a composite sample in a zigzag movement between the planting lines, and collection at the depths of $0-10 \mathrm{~cm}, 10-20 \mathrm{~cm}, 20-30 \mathrm{~cm}$ and $30-40 \mathrm{~cm}$.

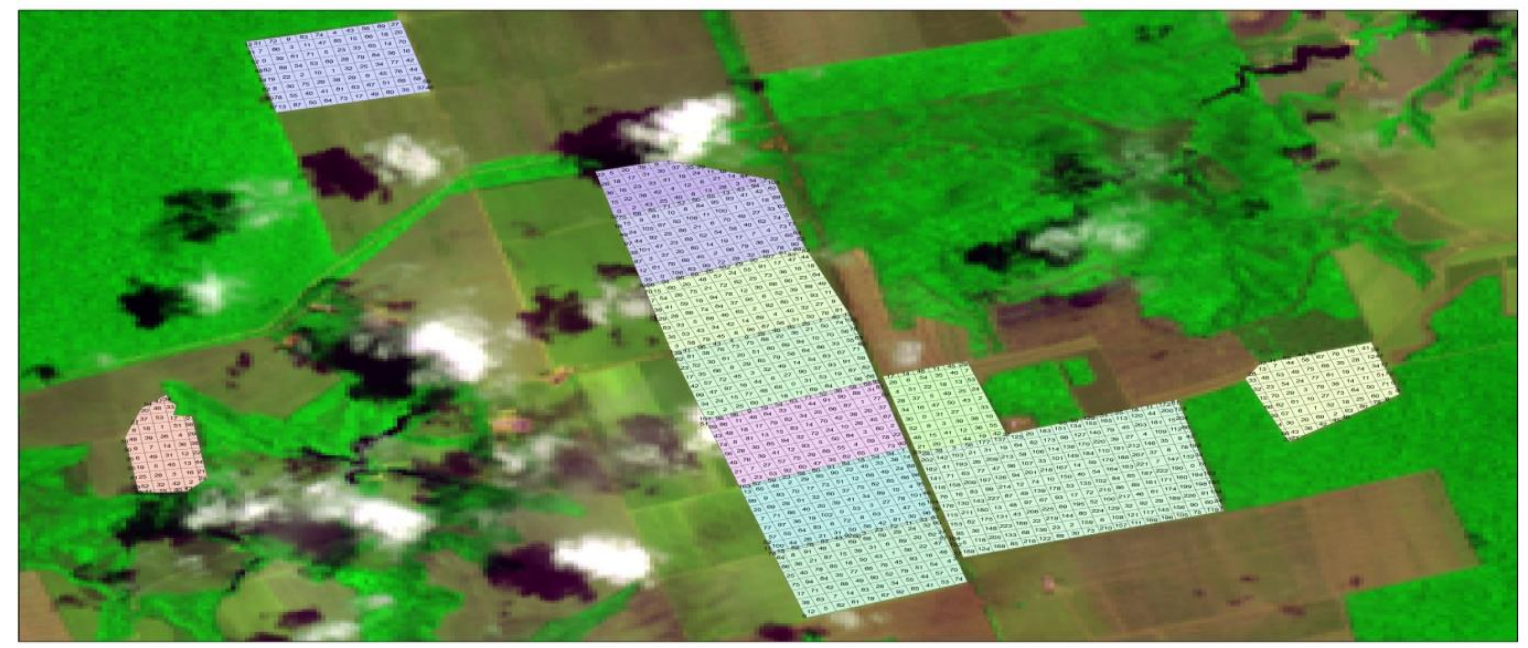

Figure 1. Satellite images of the study areas with demarcation of the polygons and grids numbered every $100 \mathrm{~m}$ for soil sampling procedure in the municipality of Paragominas, PA.

(Source: Google Earth, ArcGIS)

\section{Phosphorus fractioning}

For the chemical fractionation of P, it was used the method described by Hedley et al. (1982), modified by Condron and Goh (1989). The inorganic phosphorus (Pi) in the extracts of

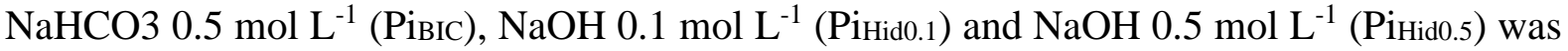
determined using the method of Dick and Tabatabai (1977). The Pi in anion-exchange resin extracts - AER ( $\left.\mathrm{Pi}_{\mathrm{AER}}\right), \mathrm{HCl} 1.0 \mathrm{~mol} \mathrm{~L}^{-1}\left(\mathrm{Pi}_{\mathrm{HCl}}\right)$ and the $\mathrm{P}$ residual digestion $\left(\mathrm{P}_{\text {residual }}\right)$ were determined through the method of Murphy and Riley (1962). For the determination of total $\mathrm{P}$ in the extracts of $\mathrm{NaHCO} 30.5 \mathrm{~mol} \mathrm{~L}^{-1}, \mathrm{NaOH} 0.1 \mathrm{~mol} \mathrm{~L}^{-1}$ and $\mathrm{NaOH} 0.5 \mathrm{~mol} \mathrm{~L}^{-1}$, aliquots of solution were mixed with ammonium persulfate and sulfuric acid 1:1: $\mathrm{H}_{2} \mathrm{O}$ and autoclaved (USEPA, 1971). The difference between total $\mathrm{P}$ and $\mathrm{Pi}$ extracted by each $0.5 \mathrm{~mol} \mathrm{~L}^{-1} \mathrm{NaHCO}_{3}$ extract, $0.1 \mathrm{~mol} \mathrm{~L}^{-1} \mathrm{NaOH}$ and $0.5 \mathrm{~mol} \mathrm{~L}^{-1} \mathrm{NaOH}$ corresponds to organic phosphorus (Po), Poвic, PoHid0.1 and PoHid0.5, respectively. The residual $\mathrm{P}$ was determined in the soil that remained after extractions through drying in an oven and grinding and by the method of Brookes and Powson (1981) The sum of all fractions corresponds to the total soil P.

\section{Statistical analysis}

The normality and homogeneity of variance for the phosphorus fraction data were tested using the Shapiro-Wilk tests. As both assumptions were rejected, the Kruskal-Wallis non-parametric test was used. When the Kruskal-Wallis null hypothesis was rejected, comparisons were made in pairs by Bonferroni's post-hoc to compare the differences between the treatment means. The experimental results were submitted to principal component analysis (PCA), in order to analyze the interrelationships between the variables related to the $P$ fractions with the other chemical and mineralogical variables of the soil. 


\section{MInstitute"}

\section{Results and Discussion}

Fractions of labile P per $P i_{A E R}, P i_{B I C}$ and PoBIC

The Piaer, Pibic and Pobic fractions in the soil are estimates of labile P (Table 3) and directly contribute to the supply of P to plants (Rodrigues et al., 2015). Significant increases were observed over NT adoption period for P content of the PiAER and PiBIC and PoBIC fractions, in the first $20 \mathrm{~cm}$ of the soil. At this depth, both PiAER and PiBIC were superior in the areas under NT and CS, in relation to the NF area, which suggests the contribution of phosphate fertilization applied during previous agricultural cultivation cycles (Table 3). This behavior has been reported in some studies (Zamuner et al., 2008; Dos Santos et al., 2008; Pavinato et al., 2009; Rodrigues et al., 2015) and can be attributed to the supply of P via phosphate fertilization ( Pavinato and Rosolem, 2008), the increase in organic matter that contributes to the reduction of $\mathrm{Pi}$ adsorption and the conversion of $\mathrm{Pi}$ to $\mathrm{Po}$ through the action of microorganisms (Tiecher et al., 2012a; Fink et al., 2016).

Table 3. Fractions of PiAER, PiBic e PoBic in different management systems and depths in a Yellow Latosol in the municipality of Paragominas, PA

\begin{tabular}{|c|c|c|c|c|c|}
\hline \multirow{2}{*}{$\begin{array}{l}\text { Depth } \\
(\mathrm{cm})\end{array}$} & \multicolumn{5}{|c|}{ management systems } \\
\hline & NF & CS & NT9 & NT11 & NT13 \\
\hline & \multicolumn{5}{|c|}{---------------------------------'mg kg-1'------------------------------- } \\
\hline & \multicolumn{5}{|c|}{ PiAER } \\
\hline $0-10$ & $1.2 \mathrm{C}$ & $3.4 \mathrm{~B}$ & $3.4 \mathrm{~B}$ & $2.6 \mathrm{~B}$ & $5.8 \mathrm{~A}$ \\
\hline $10-20$ & $1.0 \mathrm{~B}$ & $1.5 \mathrm{~B}$ & $2.4 \mathrm{~A}$ & $2.3 \mathrm{~A}$ & $2.7 \mathrm{~A}$ \\
\hline $20-30$ & $1.0 \mathrm{~B}$ & $1.1 \mathrm{~B}$ & $2.8 \mathrm{~A}$ & $1.2 \mathrm{~B}$ & $1.4 \mathrm{~B}$ \\
\hline \multirow[t]{2}{*}{$30-40$} & $1.0 \mathrm{~A}$ & $1.0 \mathrm{~A}$ & $1.1 \mathrm{~A}$ & $1.1 \mathrm{~A}$ & $1.0 \mathrm{~A}$ \\
\hline & \multicolumn{5}{|c|}{ PiBic } \\
\hline $0-10$ & $10.4 \mathrm{~B}$ & $18.1 \mathrm{AB}$ & $25.3 \mathrm{AB}$ & $32.7 \mathrm{~A}$ & $32.2 \mathrm{~A}$ \\
\hline $10-20$ & $5.8 \mathrm{~B}$ & $7.1 \mathrm{AB}$ & $15.6 \mathrm{AB}$ & $24.0 \mathrm{~A}$ & $22.9 \mathrm{~A}$ \\
\hline $20-30$ & $4.5 \mathrm{~B}$ & $8.0 \mathrm{AB}$ & $10.5 \mathrm{AB}$ & $16.4 \mathrm{~A}$ & $3.2 \mathrm{~B}$ \\
\hline \multirow[t]{2}{*}{$30-40$} & 4.6 AB & $4.7 \mathrm{AB}$ & $9.2 \mathrm{~A}$ & $3.5 \mathrm{AB}$ & $2.1 \mathrm{~B}$ \\
\hline & \multicolumn{5}{|c|}{ PoBic } \\
\hline $0-10$ & $19.2 \mathrm{~B}$ & $6.4 \mathrm{~B}$ & $30.8 \mathrm{~A}$ & $39.9 \mathrm{~A}$ & $61.4 \mathrm{~A}$ \\
\hline $10-20$ & $8.0 \mathrm{~B}$ & $7.1 \mathrm{~B}$ & $23.7 \mathrm{AB}$ & $28.4 \mathrm{~A}$ & $24.2 \mathrm{AB}$ \\
\hline $20-30$ & $7.3 \mathrm{~B}$ & $7.3 \mathrm{~B}$ & $28.4 \mathrm{AB}$ & $24.6 \mathrm{AB}$ & $55.7 \mathrm{~A}$ \\
\hline $30-40$ & $8.7 \mathrm{~B}$ & $3.5 \mathrm{~B}$ & $6.5 \mathrm{~B}$ & $12.6 \mathrm{~B}$ & $50.2 \mathrm{~A}$ \\
\hline
\end{tabular}


*Means followed by the same letter are not different by the test of Kruskal-Wallis $(\mathrm{p}<0.05)$.

In the most superficial layers $(0-30 \mathrm{~cm}), \mathrm{CS}$ had the lowest levels of $\mathrm{P}$ in the PoвIC fraction, compared to NT and NF. In the toplayer $(0-10 \mathrm{~cm})$, the area with the longest period of the no-tillage system (NT13) presented Poвic contents higher than that observed in the areas of this system (NT11 and NT9), which suggests a tendency to increase PoBIC as the adoption time increases (Table 3). The Poвic fraction is closely associated with easily decomposed organic compounds, both of microbial and plant origin (Sá et al. 2001; Lopes et al., 2004; Bravo et al., 2007). Therefore, the frequent supply of plant material to the soil surface of the areas under no-tillage (Rheinheimer and Anghinoni, 2003), added to the conversion of Pi to Po, by incorporating Pi into microbial tissue or plant tissue with high biomass production, such as grasses (corn and Brachiaria Ruziziensis) (Carneiro et al., 2011; Conte et al., 2003; Vincent et al., 2010), may have directly contributed to the increase in PoвIc, with the time of adoption.

According to Tiecher et al. (2018), the increase in the adoption period for no-tillage promotes the activity of the soil microbiota, directly influencing the biological reactions of the $\mathrm{P}$ cycle, with an increase in Po, which, when mineralized, buffers the PiAER (P available for Biomass). Thus, in soils with low levels of available $\mathrm{P}$ and high capacity for fixing this nutrient, as is the case of Oxisols in the Amazon, the adoption of no-tillage is an excellent alternative to circumvent issues related to $P$ retention, applied via mineral fertilization.

Some studies have been conducted in other Brazilian biomes showing divergent results, when comparing the levels of $\mathrm{P}$ in the fractions considered labile (PiAER, PiBIC and PoBIC) in the soil under no-tillage system. The mean contents of PiAER in the $0-10 \mathrm{~cm}$ layer of the present study $\left(8 \mathrm{mg} \mathrm{kg}^{-1}\right)$ were lower than those obtained by Pavinato et al. (2009) in the state of Mato Grosso do Sul in the region of the Cerrado Biome (15 mg kg-1) and by Tiecher et al. (2012a) in the state of Paraná in the Atlantic Forest Biome $\left(44 \mathrm{mg} \mathrm{kg}^{-1}\right)$. However, the contents of Рівгс (30 $\mathrm{mg} \mathrm{kg}^{-1}$ ) and Ровгс $\left(45 \mathrm{mg} \mathrm{kg}^{-1}\right)$ were higher than those obtained by Pavinato et al. (2009) in the Cerrado (11 mg kg-1 of PiBIC and $12 \mathrm{mg} \mathrm{kg}^{-1}$ of PoвIC) and by Tiecher et al. (2012 a, b) in the Atlantic Forest (12 mg kg-1 of PiBIC and $30 \mathrm{mg} \mathrm{kg}^{-1}$ of PoBIC). Thus, it can be inferred that the contents of these $\mathrm{P}$ fractions in the Amazon biome differ from those obtained in the Cerrado and Atlantic Forest Biomes.

\section{Moderately labile P fractions per Pi $i_{H i d o .1,}$ PoHido.l and PiHCl}

In most depths, the highest values of the PiHido.1 fraction were also obtained with the longest time of adoption of no-tillage system (Table 4). The PiHid0.1 fraction represents Pi associated with $\mathrm{Fe}$ and $\mathrm{Al}$ oxides (Gatiboni et al., 2007). In soils with high levels of Fe and Al oxides, such as Oxisols in the Amazon, it is common to have high levels of Pi linked to oxides. In addition, with this increase in organic matter, a hallmark of the no-tillage system may inhibit the complete formation in amorphous $\mathrm{Fe}$ and $\mathrm{Al}$ oxide crystals through the bond between functional organic groups and oxides, increasing the specific surface area of $\mathrm{Fe}$ and $\mathrm{Al}$ crystals (Fink et al., 2016) besides promoting $\mathrm{P}$ adsorption in $\mathrm{Fe}$ and $\mathrm{Al}$ oxides, which explains the higher levels of $\mathrm{Pi}_{\text {Hid0.1 }}$ in no-tillage system. 
Table 4. Fractions of $\mathrm{Pi}$ Hid-0.1, Po Hid-0.1 e Pi $\mathrm{HCl}_{\mathrm{HCl}}$ in different management systems and depths in a Yellow Latosol in the municipality of Paragominas, PA

\begin{tabular}{|c|c|c|c|c|c|}
\hline \multirow[b]{2}{*}{ Depth $(\mathrm{cm})$} & \multicolumn{5}{|c|}{ management systems } \\
\hline & NF & $\mathrm{CS}$ & NT9 & NT11 & NT13 \\
\hline & \multicolumn{5}{|c|}{ 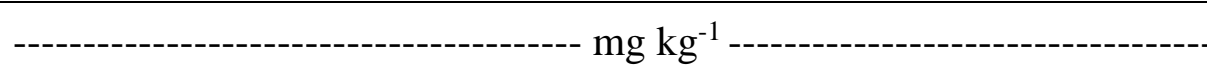 } \\
\hline & \multicolumn{5}{|c|}{ Pi ${ }_{\text {Hid- } 0.1}$} \\
\hline $0-10$ & $22.0 \mathrm{~B}$ & $39.7 \mathrm{~B}$ & $60.7 \mathrm{AB}$ & $64.6 \mathrm{AB}$ & $78.9 \mathrm{~A}$ \\
\hline $10-20$ & $8.7 \mathrm{~B}$ & $18.2 \mathrm{AB}$ & $55.3 \mathrm{~A}$ & $46.3 \mathrm{AB}$ & $64.9 \mathrm{~A}$ \\
\hline $20-30$ & $4.0 \mathrm{~B}$ & $14.3 \mathrm{AB}$ & $55.5 \mathrm{~A}$ & $50.1 \mathrm{~A}$ & $26.6 \mathrm{AB}$ \\
\hline \multirow[t]{2}{*}{$30-40$} & $3.4 \mathrm{~B}$ & $9.6 \mathrm{AB}$ & $25.1 \mathrm{~A}$ & $17.9 \mathrm{AB}$ & $20.4 \mathrm{~A}$ \\
\hline & \multicolumn{5}{|c|}{ PoHid-0.1 } \\
\hline $0-10$ & $40.6 \mathrm{~B}$ & $25.9 \mathrm{~B}$ & $103.1 \mathrm{AB}$ & $171.1 \mathrm{~A}$ & $138.5 \mathrm{~A}$ \\
\hline $10-20$ & $25.7 \mathrm{~B}$ & $25.3 \mathrm{~B}$ & $93.7 \mathrm{~A}$ & $124.4 \mathrm{~A}$ & $96.3 \mathrm{~A}$ \\
\hline $20-30$ & $28.7 \mathrm{~B}$ & $24.4 \mathrm{~B}$ & $89.7 \mathrm{~A}$ & $81.8 \mathrm{~A}$ & $30.3 \mathrm{~B}$ \\
\hline \multirow[t]{2}{*}{$30-40$} & $27.5 \mathrm{AB}$ & $18.5 \mathrm{~B}$ & $34.9 \mathrm{~A}$ & $29.7 \mathrm{AB}$ & $25.1 \mathrm{AB}$ \\
\hline & \multicolumn{5}{|c|}{$\mathrm{PiHCl}_{\mathrm{H}}$} \\
\hline $0-10$ & $1.1 \mathrm{~B}$ & $2.3 \mathrm{AB}$ & $2.5 \mathrm{AB}$ & $2.1 \mathrm{AB}$ & $3.2 \mathrm{~A}$ \\
\hline $10-20$ & $1.0 \mathrm{~B}$ & $1.5 \mathrm{AB}$ & $1.0 \mathrm{~B}$ & $2.4 \mathrm{AB}$ & $3.0 \mathrm{~A}$ \\
\hline $20-30$ & $1.0 \mathrm{~B}$ & $1.0 \mathrm{~B}$ & $1.0 \mathrm{~B}$ & $1.0 \mathrm{AB}$ & $2.4 \mathrm{~A}$ \\
\hline $30-40$ & $1.0 \mathrm{~B}$ & $1.0 \mathrm{~B}$ & $1.0 \mathrm{~B}$ & $1.0 \mathrm{~B}$ & $1.8 \mathrm{~A}$ \\
\hline
\end{tabular}

*Means followed by the same letter are not different by the test of Kruskal-Wallis $(\mathrm{p}<0.05)$.

Regardless of the management of the adopted system, the highest levels of PoHido.1 were observed in the topsoil $(0-10 \mathrm{~cm})$, resulting from the higher content of organic matter in this layer (Table 2). This fraction showed a similar behavior to that observed in the PiHid0.1 fraction in the same layer, but with slightly higher values (Table 4). In the 10-20 cm layer, a significant depletion in PoHid-0.1 was observed NT11 to NT13. Concomitantly, there was an increase in PiHid0.1 (Table 4), which indicates a possible mineralization of organic $\mathrm{P}$ and, a consequent reabsorption in the PiHid0.1 fraction. In the subsequent layers, 20-30 and 30-40 cm, the opposite behavior is observed, in which the areas under less adoption time of no-tillage system (NT9 and NT11) were superior to the other treatments, which can be explained by the higher content of organic matter in these treatments (Table 2).

According to studies carried out by Souza et al. (2007), the increase in PoHid0.1 contents with the time of adoption of no-tillage is very important in the $\mathrm{P}$ dynamics as the PoHid0.1 fraction can behave as a reservoir through Po mineralization by acid phosphatases, with a consequent 
buffering of the most available fractions of P (Novais et al., 2007; Tiecher et al., 2018).

In studies conducted in Goiás - Cerrado Biome, in soil under no-tillage system, Rodrigues et al. (2016) and Pavinato et al. (2009) obtained opposite results to the present study, with larger and smaller contents of PiHid0.1 (70 and $140 \mathrm{mg} \mathrm{kg}^{-1}$, respectively) and Po Hid0. 1 (75 and $77 \mathrm{mg}$ $\mathrm{kg}^{-1}$, respectively), respectively, than those found in this study (Piнid0.1: $69 \mathrm{mg} \mathrm{kg}^{-1}$ and PoHido.1: $137 \mathrm{mg} \mathrm{kg}^{-1}$ ). It is observed that unlike the Cerrado, there is a predominance of Po in the Amazon region. However, when comparing the results with studies carried out in the South region of Brazil, Atlantic Forest Biome, a similar behavior to the Amazon Biome is observed, with a predominance of PoHid0.1 (186 mg kg-1 (Soltangheisi et al., 2018), $414 \mathrm{mg}$ $\mathrm{kg}^{-1}$ (Tiecher et al., 2012b) compared to PiHid 0.1 (29 $\mathrm{mg} \mathrm{kg}^{-1}$ (Soltangheisi et al., 2018), $60 \mathrm{mg}$ $\mathrm{kg}^{-1}$ (Tiecher et al., 2012a)). In addition, it is found higher levels of PoHid0.1 and lower levels of PiHid0.1 in the region of the Atlantic Forest Biome in relation to the Amazon biome, therefore, there is a clear differentiation between types of Biome in the dynamics of $\mathrm{P}$ fractions. Thus, it is observed that the dynamics of $\mathrm{P}$ fractions are sensitive to the Biome in which the soil is inserted. Soil management under no-tillage system in the Amazon Biome showed contents of $\mathrm{PiHCl}_{\mathrm{H}}$ relatively low, which may be explained by the fact that the soil is highly weathered, with a very low content of apatitic minerals and since $\mathrm{HCl}$ preferentially extracts fractions of $\mathrm{P}$ linked to $\mathrm{Ca}$, the levels are naturally low.

\section{Non-labile P fraction per PiHid0.5, PoHid0.5 and $P_{\text {Residual }}$}

Overall, the PiHid0.5 values found in CS were always higher than in NF and in most depths, they were slightly higher than no-tillage system (Table 5). In general, Oxisols tend to accumulate $\mathrm{P}$ in less labile fractions, when receiving regular fertilizer additions, as commonly observed in highly weathered soils (Negassa and Leinweber, 2009). Thus, when the soil is managed under CS, this process can be benefited, since there is a larger contact between the fertilizer $\mathrm{Pi}$ and the inorganic constituents of the soil, favoring the adsorption of $\mathrm{P}$ in less available fractions, such as $\mathrm{P}_{\mathrm{iHid} 0.5 \text {. }}$ 
Table 5. Fractions of PiHid-0.5, PoHid-0.5 e Presidual in different management systems and depths in a Yellow Latosol in the municipality of Paragominas, PA

\begin{tabular}{|c|c|c|c|c|c|}
\hline \multirow[b]{2}{*}{ Depth $(\mathrm{cm})$} & \multicolumn{5}{|c|}{ management systems } \\
\hline & NF & CS & NT9 & NT11 & NT13 \\
\hline & \multicolumn{5}{|c|}{----------------------------------------- $\mathrm{mg} \mathrm{kg}^{-1}$ - } \\
\hline & \multicolumn{5}{|c|}{ PiHid-0.5 } \\
\hline $0-10$ & $33.0 \mathrm{~A}$ & $58.2 \mathrm{~A}$ & $40.8 \mathrm{~A}$ & $40.0 \mathrm{~A}$ & $60.1 \mathrm{~A}$ \\
\hline $10-20$ & $32.1 \mathrm{~A}$ & $45.8 \mathrm{~A}$ & $30.5 \mathrm{~A}$ & $29.8 \mathrm{~A}$ & $44.6 \mathrm{~A}$ \\
\hline $20-30$ & $26.0 \mathrm{~A}$ & $32.8 \mathrm{~A}$ & $31.2 \mathrm{~A}$ & $29.7 \mathrm{~A}$ & $31.5 \mathrm{~A}$ \\
\hline \multirow[t]{2}{*}{$30-40$} & $21.4 \mathrm{AB}$ & $39.0 \mathrm{~A}$ & $28.8 \mathrm{AB}$ & $43.9 \mathrm{~A}$ & $15.8 \mathrm{~B}$ \\
\hline & \multicolumn{5}{|c|}{ PoHid-0.5 } \\
\hline $0-10$ & $57.0 \mathrm{~B}$ & $64.7 \mathrm{AB}$ & $122.7 \mathrm{~A}$ & $86.5 \mathrm{AB}$ & $119.0 \mathrm{~A}$ \\
\hline $10-20$ & $44.5 \mathrm{~B}$ & $38.8 \mathrm{~B}$ & $66.5 \mathrm{AB}$ & $113.7 \mathrm{~A}$ & $45.9 \mathrm{~B}$ \\
\hline $20-30$ & $33.3 \mathrm{~B}$ & $7.8 \mathrm{~B}$ & $68.2 \mathrm{AB}$ & $76.7 \mathrm{~A}$ & $58.6 \mathrm{AB}$ \\
\hline \multirow[t]{2}{*}{$30-40$} & $27.9 \mathrm{~B}$ & $0.8 \mathrm{C}$ & $52.5 \mathrm{~A}$ & $40.0 \mathrm{AB}$ & $43.5 \mathrm{AB}$ \\
\hline & \multicolumn{5}{|c|}{$P_{\text {Residual }}$} \\
\hline $0-10$ & $689 \mathrm{~B}$ & $586 \mathrm{~B}$ & $1007 \mathrm{~A}$ & $625 B$ & $625 B$ \\
\hline $10-20$ & $646 \mathrm{~A}$ & $633 \mathrm{~A}$ & $654 \mathrm{~A}$ & $608 \mathrm{~A}$ & $737 \mathrm{~A}$ \\
\hline $20-30$ & $612 \mathrm{~A}$ & $651 \mathrm{~A}$ & $666 \mathrm{~A}$ & $634 \mathrm{~A}$ & $661 \mathrm{~A}$ \\
\hline $30-40$ & $613 \mathrm{~A}$ & 592 B & $614 \mathrm{~A}$ & $612 \mathrm{~A}$ & $710 \mathrm{AB}$ \\
\hline
\end{tabular}

*Means followed by the same letter are not different by the test of Kruskal-Wallis $(p<0.05)$.

Regardless of the depth, the longer no-tillage adoption time resulted in higher values of the PoHid0.5 fraction (Table 5), in relation to those observed in CS and NF. At a depth of 20-30 cm, the highest levels of PoHid-0.5 were observed in NT9, NT11 and NT13, while the lowest were those obtained in CS. At a depth of 30-40 cm, NT9 showed the highest levels of PoHid-0.5, which was superior to the other treatments. The organic fraction extracted by $\mathrm{NaOH} 0.5 \mathrm{~mol}$ $\mathrm{L}^{-1}$ showed a wide variation between treatments and depths, which does not allow a clear conclusion because of the significant fluctuations in PoHid0.5 levels. Similar behavior was also observed by Pavinato and Rosolem (2008), when characterizing the changes in the availability and forms of $\mathrm{P}$ in the soil, in depth, with the addition of organic compounds from plants in soil cultivated for a long time under conventional system and no-tillage system. 
According to the author, the large variation in the data may be caused by the way in which they are obtained, since the organic fraction is obtained from the difference between the fraction of total $\mathrm{P}$ extracted by $\mathrm{NaOH} 0.5 \mathrm{~mol} \mathrm{~L}^{-1}$ and the inorganic fraction extracted by this same extractor.

When evaluating the long-term changes promoted by no-tillage and conventional systems in fertility and P fractions in Cerrado soils, Rodrigues et al. (2015) observed that PoHid0.5 contents were higher in no-tillage than in the CS in all clayey soils, confirming the results obtained in this work.

Pavinato et al. (2009) in an experiment with no-tillage system in the Cerrado Biome region, obtained higher levels of PiHid0.5 (100 mg kg-1) and lower levels of PoHid0.5 (45 mg kg-1) compared to the levels obtained in this study (PiHid0.5: $47 \mathrm{mg} \mathrm{kg}^{-1}$, PoHid0.5: $110 \mathrm{mg} \mathrm{kg}^{-1}$ ). Teles et al. (2017) in studies conducted in the Atlantic Forest Biome in Paraná, found the largest of both fractions: Pi Hid0.5 (129 mg kg-1) and Po Hid0.5 (135 $\left.\mathrm{mg} \mathrm{kg}^{-1}\right)$. In addition, it is observed that Po Hid0.5 in the present experiment conducted in the Amazon Biome region is more than the double of PiHid0.5 while in the Cerrado Biome the opposite occurs and in the Atlantic Forest Biome, the behavior is similar to that of Amazon biome, but with smaller differences between the values of Pi Hid0.5 and PoHid0.5.

In general, values of PResidual were very high (Table 5). This fraction showed some stability in the soil, with no statistical difference between the evaluated management systems. PResidual represents the $\mathrm{P}$ associated with hematite, goethite and gibbsite, which are abundant in the studied soil, therefore explaining the high levels of this fraction (Souza et al., 2007). According to Novais and Smyth (1999) and Pinto et al. (2013), in more clayey soils, there is a greater amount of Lewis acidic sites, thus favoring $\mathrm{P}$ adsorption, which initially increases in the levels of labile P. However, over the contact period, $\mathrm{P}$ goes to less available fractions. Furthermore, in soils with greater phosphate adsorption capacity, higher proportions of $\mathrm{P}$ must be adsorbed with high energy and only extracted with soil digestion $\left(\mathrm{H}_{2} \mathrm{SO}_{4}+\mathrm{H}_{2} \mathrm{O}_{2}\right)$ (Cross and Schlesinger, 1995). According to Yang and Post (2011), the Presidual increases as weathering progresses, reaching $20 \%$ of the total $\mathrm{P}$ in poorly weathered soils, while in highly weathered soils, the content of $\mathrm{P}_{\text {Residual }}$ can reach $60 \%$ of the P-total. In this study, $\mathrm{P}_{\text {Residual }}$ corresponded on average, to $80 \%$ of the $\mathrm{P}_{\text {total }}$ of the soil (Figure 2).

Regarding the values, the average contents of $\mathrm{P}_{\text {residual }}\left(752 \mathrm{mg} \mathrm{kg}^{-1}\right)$ in the soil under no-tillage system were higher than those observed in other Brazilian regions. Rodrigues et al. (2015) when observing the behavior of $\mathrm{P}$ fractions in soil under no-tillage, in Goiás (Cerrado Biome), obtained an average content of $\mathrm{P}_{\text {residual }}$ of $400 \mathrm{mg} \mathrm{kg}^{-1}$. Also, when evaluating the $\mathrm{P}$ fractions in soil under no-tillage, but in Paraná (Atlantic Forest Biome), Soltangheisi et al. (2018) observed average levels of Presidual of $600 \mathrm{mg} \mathrm{kg}^{-1}$. Therefore, it is observed that the behavior and magnitude of values of the $\mathrm{P}$ fractions, from the labile to the non-labile fraction, can be modified according to the biome to which the no-tillage system is inserted, which allows us to infer that there is a differentiation between the types of biomes existing in Brazil.

It can be seen in the results the large amount of $\mathrm{P}$ accumulated in this soil in fractions considered unavailable for plants, especially in the $\mathrm{P}_{\text {residual }}$ fraction. These unavailable 
fractions of $\mathrm{P}$ are a potentially valuable resource of this nutrient but not used in the present moment. The rational and sustainable use of $\mathrm{P}$ is necessary to improve its efficiency of use and to preserve the resources of phosphate rocks for future generations. Therefore, further studies are needed to explore this residual fraction of $\mathrm{P}$ that is accumulated in soils cultivated in Brazil and thus, guarantee a more sustainable future agricultural production.

\section{Total phosphorus}

All areas under no-tillage system had higher P-Total contents than CS and NF, with higher concentrations in the topsoil compared to the subsurface layers (Table 6). This is due to the non-incorporation of the fertilizers added on the surface, to the lower losses caused by erosion and, also, to the cycling of nutrients by the plants, in which they absorb the $\mathrm{P}$ from the deeper layers, recycling it to the surface, when their residues decompose (Rheinheimer and Anghinoni, 2001).

Table 5. P-Total in different management systems and depths in a Yellow Latosol in the municipality of Paragominas, PA

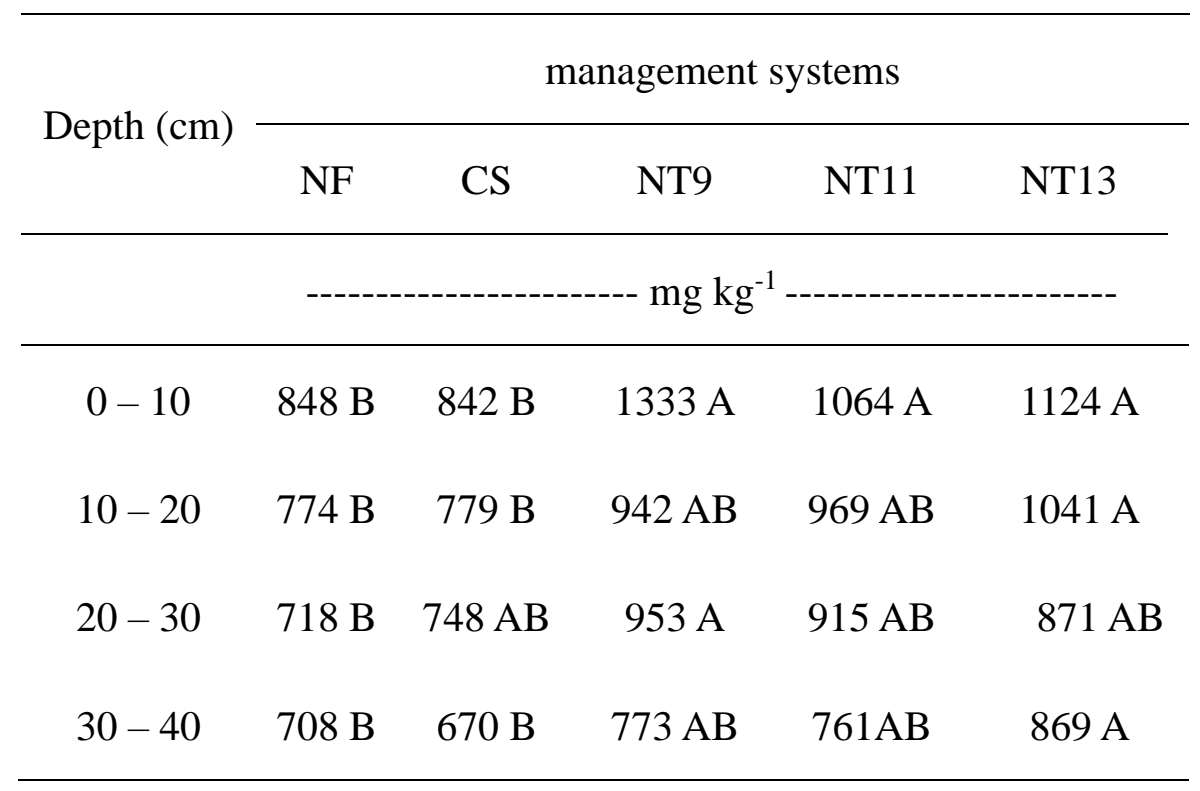

*Means followed by the same letter are not different by the test of Kruskal-Wallis $(\mathrm{p}<0.05)$.

The percentage of contribution of each $\mathrm{P}_{\text {total }}$ fraction is shown in Figure 2. In all management systems, regardless of depth, the proportion of PResidual was greater than $80 \%$ of the total $\mathrm{P}$ content found in the experiment, showing the fixative characteristic of the soil in the studied area. However, the NT reduced this fraction by up to $12 \%$, and also increased the proportion of fractions with greater availability, such as Pires, Piвic Poвic, PiHido.1 PoHid0.1, compared to CS and NF. The predominance of PResidual in the P-Total can be attributed to the characteristic of the type of soil used in the present study, which, according to Rodrigues et al. (2015), tends to accumulate $\mathrm{P}$ in more recalcitrant fractions when receiving regular $\mathrm{P}$ additions, as indicated by Cross and Schlesinger (1995) and confirmed by Negassa and Leinweber (2009).

The increase in the percentage contribution of $\mathrm{P}$ fractions considered more available in relation to the $\mathrm{P}_{\text {total }}$, observed in the no-tillage areas can be attributed to the reduction of the 
adsorption of $\mathrm{P}$, due to the non-revolving of the soil, with subsequent decrease of the exposure of the $\mathrm{P}$ of the fertilizer to the adsorption reactions. In addition, the presence of low molecular weight organic acids may block the $\mathrm{P}$ adsorption sites and reduce the adsorption of the nutrient, promoting the remaining of $\mathrm{P}$ in more available fractions (Hue, 1991; Rheinheimer and Anghinoni, 2001; Rheinheimer et al., 2008).

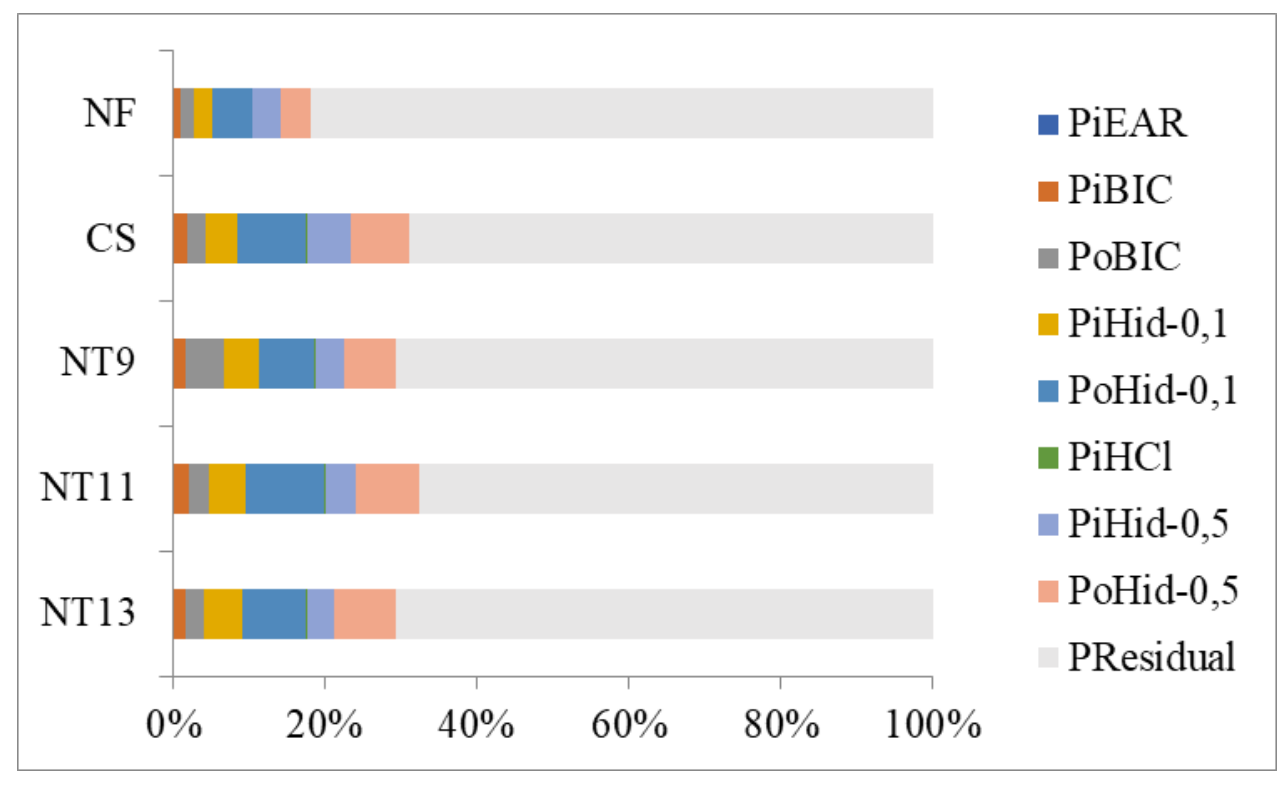

Figure 2. Percentage contribution of different $\mathrm{P}$ fractions in relation to the $\mathrm{P}$-Total of a dystrophic Yellow Latosol under different management systems in Paragominas, PA

Principal component analysis (PCA) was used to reduce the dimensions of the data and, consequently, to facilitate the analysis through the correlation circle graph. The PCA

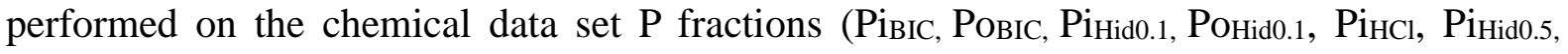
Pohid0.5, Presidual), available $\mathrm{P}\left(\mathrm{Mehlich}^{-1}\right)$, $\mathrm{P}$ total, attributes chemicals (SB, pH, Al, Ca), mineralogical components (clay, Feox, FedcB) and organic matter (Figure 3), revealed that the first two axes explained $64.2 \%$ of the total variability of the data. The first component explained $49.73 \%$ and the second, $14.40 \%$ (Figure 3).

The variables associated with PC1 were the PiRes, Piвic, Poвic, Piнid0.1, PoHid0.1, Pohid0.5, P Total, $\mathrm{OM}, \mathrm{Fe}$ and $\mathrm{CEC}$, with positive eigenvectors and Total $\mathrm{Fe}$ and clay, with negative eigenvectors. $\mathrm{PC} 2$ was composed by $\mathrm{SB}, \mathrm{pH}, \mathrm{Ca}$, with positive eigenvectors, and $\mathrm{PiHCl}$, PResidual, FeDCB, Al, H + Al, with negative eigenvectors. The PCA shows that there was a high positive correlation between the available $\mathrm{P}$, PiBIC, PoвIC, $\mathrm{Pi}_{\text {Hid } 0.1}$, PoHid0.1, PoHid0.5, total $\mathrm{P}$ and CEC (Figure 3), as well as a high positive correlation between PiHid0.5 and PRTA. The high correlation between fractions considered more labile and less labile (such as $\mathrm{P}$ extracted by $\mathrm{NaOH}$ ), reinforces the hypothesis that less available forms of $\mathrm{P}$ can buffer labile $\mathrm{P}$ from the soil. 


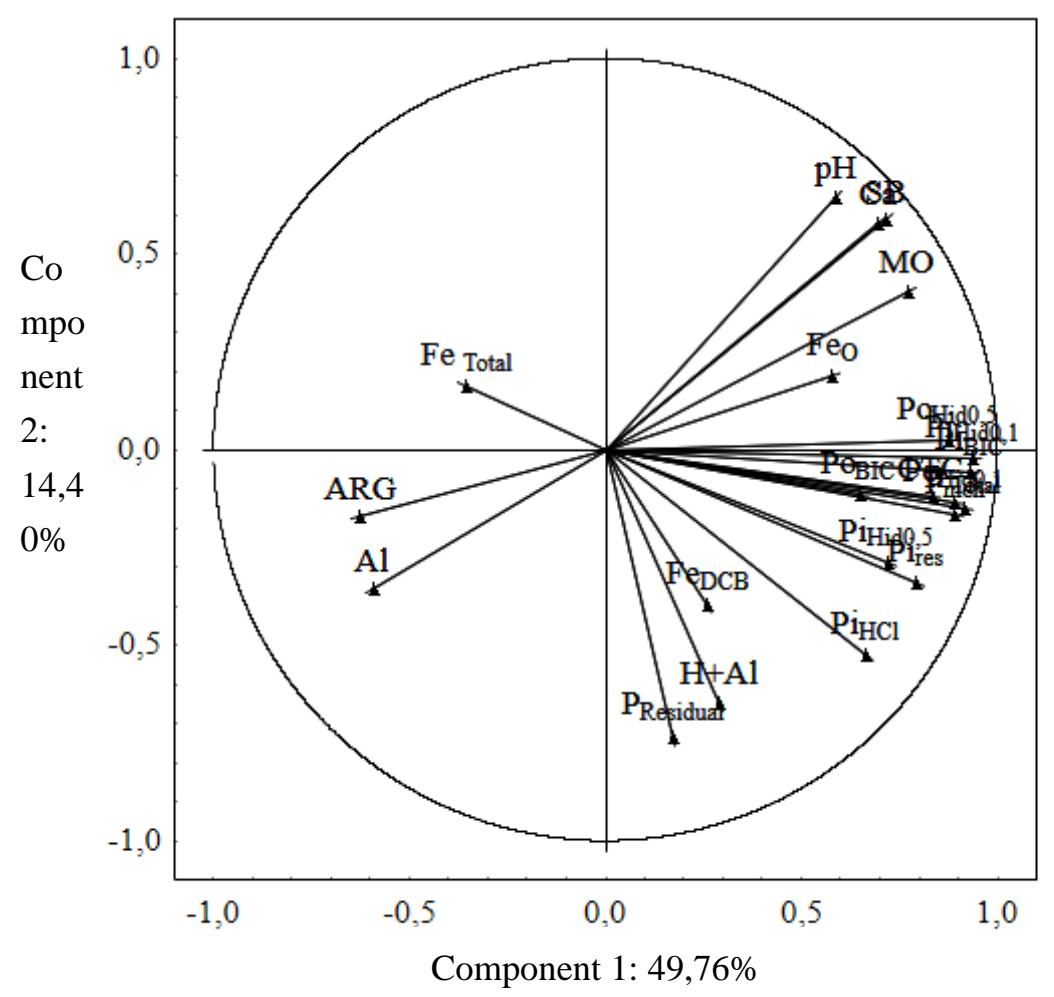

Figure. 3. Circle of correlations between the variables Clay, $\mathrm{pH}, \mathrm{H}+\mathrm{Al}, \mathrm{Al}^{3+}, \mathrm{Ca}, \mathrm{CEC}$ (cation exchange capacity), SB (sum of bases), V (base saturation), P (Mehlich 1), PAER, PiBIC and Poвı, PiHido.1 and Pohid0.1, PiнCl, Pihid0.5 and PoHid0.5, P Residual, OM, Fe Total and $\mathrm{P}_{\text {Total, }}, \mathrm{Fe}_{\text {oxa }}$ (amorphous iron oxides), Fе management in Paragominas, PA

The cluster analysis between the principal components 1 and 2, allowed to forming three groups (Figure 4). Group 1 was formed by Piвгс, Ровге, Piнid0.1, Pонid0.1, Piнсl, Piнid0.5, Pонid0.5, $\mathrm{P}$ available, Total $\mathrm{P}, \mathrm{OM}, \mathrm{FeO}, \mathrm{pH}, \mathrm{CEC}, \mathrm{SB}$ and $\mathrm{Ca}$. Group 2 was composed by $\mathrm{P}_{\text {Residual }} \mathrm{H}+$ $\mathrm{Al}, \mathrm{Fe}$ DCB and group 3 by Al, clay and Total Fe. 


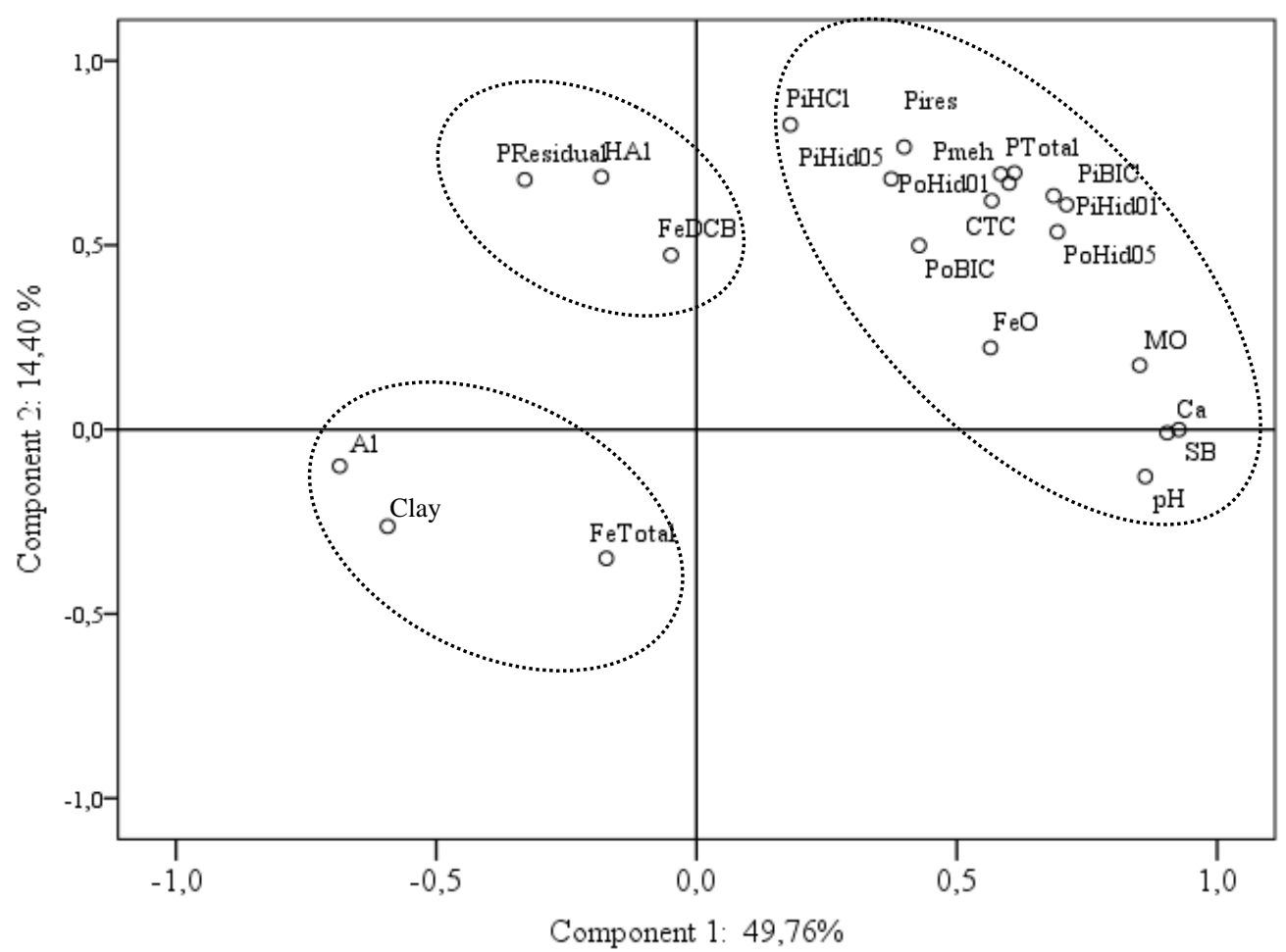

Figure 4. Graphical dispersion of the relationship of the first two principal components based on the chemical and mineralogical characteristics of an Oxisol under different management systems in Paragominas, PA

The graphical dispersion of the fractions with the different soil attributes (Figure 4) demonstrates a high relationship and similarity between the $\mathrm{P}$ fractions and the chemical attributes of the soil and dissimilarity and antagonism to the mineralogical components of the soil (Clay, contents of total Fe and FeDCB).

\section{Conclusion}

The levels of $\mathrm{P}$ of the fractions ( $\mathrm{P} \mathrm{i}_{\mathrm{AER}}, \mathrm{Pi}_{\mathrm{BIC}}$ and $\mathrm{PoBIC}$ ) $\mathrm{P}$ labile, increase due to the raise in the time of adoption of the no-tillage system, in the first $10 \mathrm{~cm}$ depth layer.

The no-tillage system results in significant increases in all phosphorus fractions in the $0-20 \mathrm{~cm}$ layer, compared to the conventional system and native vegetation.

Among the $\mathrm{P}$ fractions of the soil under no-tillage, the organic fractions were higher than the inorganic fractions, therefore showing greater effectiveness of the no-tillage system in the Amazon Biome in relation to the $\mathrm{P}$ dynamics in the soil.

\section{References}

Barej, J. A. M., Patzolda, S., Perkonsb, U., \& Amelunga, W. (2014). Phosphorus fractions in bulk subsoil and its biopore systems. European journal of soil Science, 65, 553-561. https://doi.org/10.1111/ejss.12124

Bastos, T. X., Pacheco, N. A., \& Figueiredo, R. O. Frequência de chuva e ocorrência de seca 
na microrregião de Paragominas, PA. 83p.

Brasil. Ministério da Agricultura, Pecuária e Abastecimento. Projeções do Agronegócio: Brasil 2017/18 a 2027/28 projeções de longo prazo / Ministério da Agricultura, Pecuária e Abastecimento. Secretaria de Política Agrícola. - Brasília : MAPA/ACE, 2018. 112 p.

Bravo, C. A., Giraldez, J. V., Ordonez, R., Gonzales, P., \& Torres, F. P. (2007). Long-term influence of conservation tillage on chemical properties of surface horizon and legume crops yield in a vertical of Southern Spain. Soil Science, 172, 141-148. https://doi.org/10.1016/j.soilbio.2010.05.020Get rights and content

Brookes, P. C., \& Powlson, D. S. (1981). Preventing phosphorus losses during perchloric acid digestion of sodium bicarbonate soil extracts. Journal of Science and Food Agriculture, 32,671-674. https://doi.org/10.1002/jsfa.2740320707

Carneiro, L. F., de Resende, A. V., Furtini Neto, A. E., Santos, J. Z. L., Curi, N., Reis, T. H. P., $\&$ do Valle, L. A. R. (2011). Frações de fósforo no solo em resposta à adubação fosfatada em um Latossolo com diferentes históricos de uso. Embrapa Milho e Sorgo-Artigo em periódico indexado (ALICE). https://www.alice.cnptia.embrapa.br/handle/doc/907436

Condron, L. M., Goh, K. M., \& Newman, R. H. (1985). Nature and distribution of soil phosphorus as revealed by a sequential extraction method followed by 31P nuclear magnetic resonance analysis. Journal of Soil Science, 36, 199-207. https://doi.org/10.1111/j.1365-2389.1985.tb00324.x.

Conte, E., Anghinoni, I., \& Rheinheimer, D. S. (2003). Frações de fósforo acumuladas em Latossolo argiloso pela aplicação de fosfato no sistema plantio direto. Revista Brasileira de Ciência do Solo, 27, 893-900. https://doi.org/10.1590/S0100-06832003000500014.

Costa, S. E. V. G de A, Souza, E. D., Anghinoni, I., Flores, J. P. C., \& Andriguetti, M. H. (2009). distribuição de potássio e de raízes no solo e crescimento de milho em sistemas de manejo do solo e da adubação em longo prazo. Revista Brasileira de Ciência do Solo, 33, 1291-1301. https://doi.org/10.1590/S0100-06832009000500022.

Cross, A. F., \& Schlesinger, W. H. (1995). A literature review and evaluation of the Hedley fractionation: Aplications to the biogeochemical cycle of soil phosphorus in natural ecosystems. Geoderma, 64, 197-214. https://doi.org/10.1016/0016-7061(94)00023-4

De Oliveira, C. M. B., Erich, M. S., Gatiboni, L. C., \& Ohno, T. (2015). Phosphorus fractions and organic matter chemistry under different land use on Humic Cambisols in Southern Brazil. Geoderma Regional, 5, 140-149. https://doi.org/10.1016/j.geodrs.2015.06.001

Dick, W. A., \& Tabatabai, M. A. (1977). Determination of or thophosphate in aqueous solutions containing labile organic and inorganic phosphorus compounds. Journal of Environmental Quality, 6, 82-85. https://doi.org/10.2134/jeq1977.00472425000600010018x

Donagema, G. K., de Campos, D. B., Calderano, S. B., Teixeira, W. G., \& Viana, J. M. (2011). Manual de métodos de análise de solo. Embrapa Solos-Documentos (INFOTECA-E). Available 
https://www.agencia.cnptia.embrapa.br/Repositorio/Manual+de+Metodos_000fzvhotqk02wx 5ok0q43a0ram31wtr.pdf . Accessed in: 23 of January of 2020.

Dos Santos, D. R., Gatiboni, L. C., \& Kaminski, J. (2008). Fatores que afetam a disponibilidade do fósforo e o manejo da adubação fosfatada em solos sob sistema plantio direto. Ciência Rural, 38(2), 576-586. https://doi.org/10.1590/S0103-84782008000200049

Farias, S. C. C., Silva Junior, M. L., Ruivo, M. L. P., Rodrigues, P. G., Melo, V. S., \& Costa, A. R. (2015). Phosphorus Forms in Ultisol Submitted to Burning and Trituration of Vegetation in Eastern Amazon. Revista Brasileira de Ciência Solo, 40, 015-0198. https://doi.org/10.1590/18069657rbcs20150198

Fink, J. R., Inda, A. V., Bavaresco, J., Barrón, V., Torrent, J., \& Bayer, C. (2016). Adsorption and desorption of phosphorus in subtropical soils as affected by management system and mineralogy. Soil \& Tillage Research, 155, 62-68. https://doi.org/10.1016/j.still.2015.07.017

Frasier, I., Quiroga, A., \& Noellemeyer, E. (2016). Effect of different cover crops on C and N cycling in sorghum NT systems. Science of The Total Environment, 562, 628-639. 10.1016/j.scitotenv.2016.04.058

Gatiboni, L. C., Kaminski, J., Rheinheimer, D. S., \& Flores, J. P. C. (2007). Biodisponibilidade de formas de fósforo acumuladas em solo sob sistema plantio direto. Revista Brasileira de Ciência Solo, 31, 691-699. https://doi.org/10.1590/S0100-06832007000400010

Hedley, M. J., Stewart, J. W. B., \& Chauhan, B. S. (1982). Changes in inorganic and organic soil phosphorus fractions induced by cultivation practices and by laboratory incubations. Soil Science Society of America Journal, 46, 970-976. Doi:10.2136/sssaj1982.03615995004600050017x

Hollinger, S. E., Bernacchi, C. J., \& Meyers, T. P. (2005). Carbon budget of mature no-till ecosystem in North Central Region of the United States. Agriculture and Forest Meteorogical. 130, 59-69. https://doi.org/10.1016/j.agrformet.2005.01.005

Hue, N. V. (1991). Effects of organic acids/anions on P sorption and phytoavailability in soils with different mineralogies. Soil Science, 152, 463-471. 10.1097/00010694-199112000-00009.

Lal, R., Reicosky, D. C., \& Hanson, J. D. (2007). Evolution of the plow over 10,000 years and the rationale for no-till farming. Soil Tillage Research, 93, 1-12. https://doi.org/10.1016/j.still.2006.11.004.

Lopes, A. S., Silva, C. A., Guilherme, L. R. G., \& Wiethölter, S. (2004). Sistema plantio direto: bases para o manejo da fertilidade do solo. Associação Nacional para Difusão de Adubos. Available in: https://www.researchgate.net/publication/242466042_sistema_plantio_direto_bases_para_o_ manejo_da_fertilidade_do_solo. Accessed: 13 of march of 2020

López, M. V., Blanco-Moure, N., Limón, M. Á., \& Gracia, R. (2012). No tillage in rainfed 
Aragon (NE Spain): effect on organic carbon in the soil surface horizon. Soil Tillage Research, 118, 61-65. https://doi.org/10.1016/j.still.2011.10.012

Luizao, F. J. (2007). Ciclos de nutrientes na Amazônia: respostas às mudanças ambientais e climáticas. Ciência e Cultura, 59, 31-36. Available in: http://cienciaecultura.bvs.br/scielo.php?script=sci_arttext\&pid=S0009-67252007000300014 Accessed in: 13 of march of 2020.

Makewitz, D., Davidson, E., Moutinho, P., \& Nepstad, D. (2004). Nutrient loss and redistribution after forest clearing on a highly weathered soil in Amazonia. Ecological Applications, 14, S177-S199. https://doi.org/10.1890/01-6016

Melero, S., López-Garrido, R., Murillo, J. M., \& Moreno, F. (2009). Conservationtillage:shortand long-term effects on soil carbon fractions and enzymatic activities under Mediterranean conditions. Soil Tillage Research, 104, 292-298. https://doi.org/10.1016/j.still.2009.04.001

Murphy, J., \& Rilley, J. P. (1962). A modified single solution method for the determination of phosphate in natural waters. Analytica Chimica Acta, 27, 31-36. https://doi.org/10.1016/S0003-2670(00)88444-5.

Negassa, W., \& Leinweber, P. (2009). How does the Hedley sequential phosphorus fractionantion reflect impacto f land use management on soil phosphorus: A review?. Journal of Plant Nutrition and Soil Science, 172, 305-325. https://doi.org/0.1002/jpln.200800223

Novais, F. R., \& Smyth, T. J. (1999). Fósforo em solo e planta em condições tropicais. UFV: Viçosa. 399p.

Novais, R. F., Alvarez, V. V. H., Barros, N. F., Fontes, R. L. F., Cantarutti, R. B., \& Neves, J. C. L. (2007). Fertilidade do solo. SBCS, 133-204.

Pavinato, P. S., \& Rosolem, C. A. (2008). Disponibilidade de nutrientes no solo decomposição e liberação de compostos orgânicos de resíduos vegetais. Revista Brasileira de Ciência Solo, 32, 911-920. https://doi.org/10.1590/S0100-06832008000300001

Pavinato, P. S., Merlin, A., \& Rosolem, C. A. (2009). Phophorus fractions in Brasilian Cerrado soils as effected by tillage. Soil \& Tillage Research, 105, 149-155. https://doi.org/10.1016/j.still.2009.07.001

Persson, U. M., Henders, S., \& Cederberg, C. (2014). A method for calculating a land-use change carbon footprint (LUC-CFP) for agricultural commodities-applications to Brazilian beef and soy, Indonesian palm oil. Global change biology, 20(11), 3482-3491. https://doi.org/10.1111/gcb.12635

Petter, F. A., de Lima, L. B., de Morais, L. A., Tavanti, R. F. R., Nunes, M. E., da Silva Freddi, O., \& Marimon Jr, B. H. (2017). Carbon stocks in oxisols under agriculture and forest in the southern Amazon of Brazil. Geoderma regional, 11, 53-61. https://doi.org/10.1016/j.geodrs.2017.09.001 
Pinto, F. A., Souza, E. D., Paulino, H. B., \& Carneiro, A. C. (2013). P-sorption and desorption in savanna brazilian soils as a support for phosphorus fertilizer management. Ciência Agrotecnologia, 37, 521-530. https://doi.org/10.1590/S1413-70542013000600005

Rheinheimer, D. S., \& Anghinoni, I. (2001). Distribuição do fósforo inorgânico em sistemas de manejo de solo. Pesquisa Agropecuária Brasileira, 36, 151-160. https://doi.org/10.1590/S0100-204X2001000100019

Rheinheimer, D. S., \& Anghinoni, I. (2003). Accumulation of Soil Organic Phosphorus by Soil Tillage and Cropping Systems Under Subtropical Conditions. Soil Science and Plant Analysis, 34, 2339-2354. https://doi.org/10.1081/CSS-120024068

Rheinheimer, D. S., Cassol, P. C., Kaminski, J., \& Anghinoni, I. (2008). Fósforo orgânico do solo. In: Santos, G. A., Camargo, F. A. O. Fundamentos da matéria orgânica do soloecossistemas tropicais e subtropicais. 2. ed. Metrópole, Porto Alegre, p. 65-82,

Rodrigues, M., Pavinato, P. S., Withers, P. J. A., Teles, A. P. B., \& Herrera, W. F. B. (2015). Legacy phosphorus and no tillage agriculture in tropical oxisols of the Brazilian savanna. Science of the Total Environment, 542, 1050-1061. https://doi.org/10.1016/j.scitotenv.2015.08.118

Rotta, L. R., Paulino, H. B., Anghinoni, I., Souza, E. D., Lopes, G., \& Carneiro, M. A. C. (2015). Phosphorus fractions and availability in a haplic plinthosol under no-tillage system in the brazilian cerrado. Ciência Agrotecnologia, 39, 216-224. https://doi.org/10.1590/S1413-70542015000300002

Sá, J. C. M., Cerri, C. C., Dick, A. W., Lal, R., Venske Filho, S. P., Piccolo, M. C., \& Feigl, B. E. (2001). Soil organic matter dynamics and sequestration rates for a tillage chronosequence in a Brazilian Oxisol. Soil Science Society of America Journal, 65, 1486-1499. $10.2136 /$ sssaj2001.6551486x

Santos, J. Z. L., Furtini Neto, A. E., Resende, A. V., Curi, N., Carneiro, L. F., \& Costa, S. E. V. G. A. (2008). Frações de fósforo em solo adubado com fosfatos em diferentes modos de aplicação e cultivado com milho. Revista Brasileira de Ciência Solo, 32, 705-714. https://doi.org/10.1590/S0100-06832008000200025

Soltangheisi, A., Rodrigues, M., Coelho, M. J. A., Gasperini, A. M., Sartor, L. R., \& Pavinato, P. S. (2018). Changes in soil phosphorus lability promoted by phosphate sources and cover crops. Soil \& Tillage Research. 179, 20-28. https://doi.org/10.1016/j.still.2018.01.006

Souza, R. F., Faquin, V., Andrade, A. T., \& Torres, P. R. F. (2007). Formas de fósforo em solos sob influência da calagem e adubação orgânica. Revista Brasileira de Ciência Solo, 31, 1535-1544. https://doi.org/10.1590/S0100-06832007000600030.

Tiecher T., Rheineimer, D. S., \& Calegari, A. (2012b). Soil organic phosphorus forms under diferent soil management systems and winter crops, in a long term experiment. Soil \& Tillage Research, 36, 271-281. https://doi.org/10.1016/j.still.2012.05.001

Tiecher, T., Gomes, M. V., Ambrosini, V. G., Amorim, M. B., \& Bayer, C. (2018). Assessing 


\section{Macrothink Institute ${ }^{\text {TM }}$}

linkage between soil phosphorus forms in contrasting tillage systems by path analysis. Soil \& Tillage Research, 175, 276-280. https://doi.org/10.1016/j.still.2017.09.015

Tiecher, T., Rheinheimer, D. S., Kaminski, J., \& Calegari, A. (2012a). Forms of Inorganic Phosphorus in Soil under Different Long Term Soil Tillage Systems and winter Crops. Revista Brasileira de Ciência Solo., 36, 271-281. https://doi.org/10.1590/S0100-06832012000100028

Trindade, E. F. S., Kato, O. R., Carvalho, E. J. M., \& Serafim, E. C. S. (2011). Disponibilidade de fósforo em solos manejados com e sem queima no nordeste paraense. Amazônia: Ciência \& Desenvolviemento, 6. Available in: https://ainfo.cnptia.embrapa.br/digital/bitstream/item/56520/1/n12-disponibilidade-de-fos.pdf Accessed in: 9 of october of 2019.

USEPA - United States Environmental Protection Agency. Methods of chemical analysis for water and wastes. Cincinnati: USEPA, (1971). Available in: https://nepis.epa.gov/exe/tiff2png.cgi/30000q10.png?-r+75+-g+7+d\%3a\%5czyfiles\%5cindex $\% 20$ data\%5c76thru80\%5ctiff\%5c00000255\%5c30000q10.tif. Accessed in: 12 of march of 2020

Vincent, A. G., Turner, B. L., \& Tanner, E. V. J. (2010). Soil organic phosphorus dynamics following perturbation of litter cycling in a tropical moist forest. European Journal of Soil Science, 61, 48-57. https://doi.org/10.1111/j.1365-2389.2009.01200.x

Yang, X., \& Post, W. M. (2011). Phosphorus transformations as a function of pedogenesis: A synthesis of soil phosphorus data using Hedley fractionation method. Biogeosciences, 8, 2907-2916. https://doi.org/10.5194/bg-8-2907-2011.

Zamuner, E. C., Picome, L. I., \& Echeverria, H. E. (2008). Organic and inorganic phosphorus in Mollisol soil under different tillage practices. Soil \& Tillage Research, 89(1), 70-77. https://doi.org/10.1016/j.still.2007.12.006

\section{Copyright Disclaimer}

Copyright for this article is retained by the author(s), with first publication rights granted to the journal.

This is an open-access article distributed under the terms and conditions of the Creative Commons Attribution license (http://creativecommons.org/licenses/by/4.0/). 